\title{
THE IMPACT OF DEMOGRAPHIC AND FAMILY STRUCTURE CHANGES ON INCOME DISTRIBUTION IN HUNGARY AND OECD COUNTRIES ${ }^{1}$
}

\section{Michael Förster - Anna Vindics}

\section{ABSTRACT}

This paper analyses the impact of socio-demographic trends on income inequality over the past two to three decades. The main socio-demographic trends in Hungary were largely in line with OECD-wide changes. Family structures are becoming increasingly complex and there is a growing disconnect between nuclear families and households. There has been a general retreat from marriage and a growth in both cohabitation and multigenerational households, as well as in the share of single person households. Births outside of marriage increased as well as the share of children living in other than two-parent family structures, and the number of children per household decreased. These changes in family structure fed into the broader cross-sectional development of ageing populations. However, most of these demographic changes had only a modest (upward) impact on trends in income inequality. In Hungary, three of the examined trends had a more significant impact than in other OECD countries: assortative mating; decline in the number of children; and changes in household types taken together. The inequality impact was typically larger on market than on disposable incomes, highlighting the strong inequality mitigating effect of the tax-benefit systems.

\footnotetext{
1 This article is based on analyses from the forthcoming OECD-EC report on the impact of shifting demographic and family structures on income inequality and its policy implications (OECD, in press). A summary of findings has been published in Förster and Vindics, 2020. The authors are grateful to István György Tóth, Attila Melegh, Lívia Murinkó and two anonymous referees for their constructive remarks and valuable suggestions; they have no responsibility for any remaining errors. The views expressed are not necessarily those of the OECD or its member countries.
} 
Keywords: income inequality, socio-demographic trends, ageing, family composition, Hungary, OECD

Michael Förster

Organisation for Economic Co-operation and Development (OECD)

E-mail: Michael.Forster@oecd.org

Anna Vindics

Organisation for Economic Co-operation and Development (OECD)

E-mail: Anna.Vindics@oecd.org

\section{INTRODUCTION}

Income inequality has been rising in OECD countries over the previous decades, having profound adverse implications for the economy and societies. There is an ongoing debate on the drivers and causes of this trend; some point to changes in labour markets, economic globalisation, institutions or redistribution (for a summary discussion, see Förster and Tóth, 2015). Others consider socio-demographic changes to be the main reasons behind rising inequalities as most OECD countries have seen shifts in population and household structures over the same period. Such changes stem from changing household structures and family formation practices, which feed into the broader cross-sectional developments of ageing populations as well as increasing female labour market participation and the resulting assortative mating (i.e. the degree to which individuals marry within their own income or educational group).

While such socio-demographic trends are likely to have an impact on countries' overall inequality levels, it is not clear to what extent, and even in which direction. To shed light on this issue, this article aims to identify the major socio-demographic trends of the past twenty to thirty years and their underlying reasons. It then aims to quantify the distributive impact of the identified socio-demographic trends. It concludes by a discussion about possible policy implications. The article puts Hungary in the focus, discussing similarities and differences with general OECD trends. 


\section{Adverse implications of inequality for the economy and societies}

Whether inequality is good or bad for growth have been a lively debate. Proponents argued that it incentivises entrepreneurial risk-taking and that the resulting accumulation of capital can result in larger investment in the economy. However, growing research evidence confirms that in the current setup, rising income inequality poses challenges for both the efficiency of economies and equity of societies (OECD, 2015).

The economic price of greater income inequality is the waste of human resources. In a very unequal society, lower income individuals are less able to invest in their (or their children's) education and health. Linked to this, a larger portion of the population can be out of work or trapped in low-paid, low-skilled jobs. In a more unequal society, people's network of social relationships is less likely to extend beyond their own income group leading to the exclusion of "non-elite" groups from many economic opportunities. Additionally, if inequality "squeezes" the middle class, it may reduce its demand for goods and services, slowing down economic growth (OECD, 2019a). Higher inequality is also associated with reduced trust, which may hurt businesses through higher transaction costs.

Rising inequality of incomes also raises political challenges. Inequality might erode support among higher-income individuals for public policies that do not serve their needs. Such goals might include investment in public health and education (OECD, 2018). High levels of inequality may also make it harder for societies to come to a political consensus, resulting in sudden policy shifts or governments serving the interests of their own supporters at the expense of the social optimum. It also considerably increases the lobby power of the richest individuals and companies vis-a-vis the median voter. In an extreme case, societies with a large gap between rich and poor people face the threat of political power being confined to the hands of a few wealthy individuals leading to a captured state. Income inequality can fuel populist and protectionist sentiments, while the resulting large wealth gaps can be associated with social conflicts, and higher security costs, for both businesses and governments (Keeley, 2015). 


\section{Transmission channels between socio-demographic changes and inequality}

Income is not uniformly distributed across individuals living in different household types. Such differences matter for both levels of income inequality across countries and for the way these have changed over time. Households contribute largely to the standard of living of their members by allowing them to co-operate in household production and to share economies of scale in consumption. This implies that as household size shrinks, a higher income is needed to assure the same level of economic well-being. More diversified income through more earners in the household can also help reducing economic risks. In line with this, certain demographic groups such as single earner households are overrepresented at the tails of the income distribution.

Some of the socio-demographic changes are a result of population ageing and they mirror individual changes over the life cycle. For example, higher shares of elderly can decrease household size as they typically live only with their partners without children or alone due to widowhood. Other changes stem from additional factors having an implication on living arrangements such as changes in norms (e.g. religion, gender equality) or the economy (e.g. rise in costs of education and housing). These result in, for example, a gradual movement away from the family structure of the $20^{\text {th }}$ century characterised by a male breadwinner model on the one hand, and/or an increase in assortative mating on the basis of earnings and education on the other.

Socio-demographic trends have an impact on income inequality through various channels. The most straightforward is through changes in the relative size of certain population groups. For instance, a higher share of older individuals in the population who typically have below-average incomes would imply an increase in overall inequality. However, the income position of these groups might change along with their composition. As our main focus is on trends in inequality, changes of both the level and the dispersion of income of these groups are equally important for the analysis. The relative income level of older individuals, for instance, tended to increase with regard to other age groups in many countries. Furthermore, incomes are distributed more equally among senior citizens than among younger age groups. Both these features can mitigate or even reverse the inequality increasing impact of the rising size of this population group. 


\section{METHODS AND DATA}

The analysis proceeds in two steps. First, microdata is used to identify the major socio-demographic trends and their likely impact on income distribution in a descriptive way. Those trends have an impact on inequality through various channels, as discussed above: changes in the population shares of these groups (structure), changes in their income level in relation to other groups (between-group inequality) and changes in distributional patterns within those groups (within-group inequality). We analyse all of these separately and in turn, to provide a complete picture of the likely impacts.

In a second step, the study applies a so-called shift-share analysis to assess the overall effect of socio-demographic trends on the income distribution. This analysis aims to identify the impact of change in certain socio-demographic patterns such as age structures by "freezing" their levels at the start of a chosen period, whilst leaving all other variables - whether economic, social, technological or institutional - unmodified. In providing this structure, the shift-share methodology can thus create a counter-factual so that any change in the income distribution between the two reference periods that is attributable to all factors but the change in the size of the "frozen" variable can be identified.

These estimates are useful to address the following question: what would have been the level of inequality in 2015 if the household structure, assortative mating and so forth had stayed as in 1995? While this method may under- or over-emphasize the effects of a given variable on the income distribution as it cannot disentangle the interaction between the different effects, it provides a rough estimate of the likely effects which is straightforward to interpret.

This article follows a recent application of this method (Grégoire-Marchand and Frémeaux, 2018), which uses double reweighting. First, the population structure of the latest period (mid-2010s) is re-weighted with the weights of specific variables (e.g. share of children) from the former period (mid-1990s). Income inequality is estimated for the mid-2010s, using this computed weight. The same process is then followed, but inversely - the income inequality index of the earliest period (mid-1990s) is computed using the transposed weights of children from the latest period (mid-2010s). For each period, the difference between the original inequality index and the one computed with the weight from the other period is calculated. This allows for a computation of the average of the two differences:

$$
\left(\text { index }^{2015(2015)}-\text { index }^{2015(1995)}\right)+\left(\text { index }^{1995(1995)}-\text { index }^{1995(2015)}\right)
$$


The analysis is based on household microdata from the Luxembourg Income Study Database (LIS). LIS is the largest available database of harmonised income microdata. It contains household- and person-level data on income and its components, as well as taxes and contributions, demography, employment, and expenditures in a harmonised way. This article assesses the effects on both market and disposable income. Market income is defined as gross income from labour, capital (financial and non-financial assets), private pensions and other private transfers. Disposable income is defined as market income and public cash transfers minus direct income taxes. The paper looks at changes between the mid-1990s and mid-2010s, using the closest available data years (for more information see https://www.lisdatacenter.org/our-data/lis-database/).

The key concept to capture income is household per-capita equivalised income. That means that, in a first step, all income sources of all household members are lumped together. In a second step, total household income is attributed to each household member (including children) - but not with weight unity: economies of scale in consumption imply that economic needs will not be four times as high for a household with four members than for a single person. This article uses the commonly applied 'square root' equivalence scale which divides household income by the square root of household size. This implies that, for instance, a household of four persons is assumed to have needs twice as large as one composed of a single person.

Income inequality in this article is captured by the Gini coefficient of concentration of incomes. This widely used indicator takes a value between 0 (when all persons have the same income) and 1 (when one person has all the income). The typical Gini coefficient of disposable income in the OECD area is around 0.31 in the late 2010s (OECD, 2019b).

\section{MAIN SOCIO-DEMOGRAPHIC TRENDS OF THE PAST DECADES}

The section identifies and examines the following major socio-demographic trends: ageing, retreat from marriage, decline in the number of children, increase in multigenerational co-residence and assortative mating. The first subsection discusses overall changes along these trends in population shares, relative income positions and inequality of specific population sub-groups. The following subsections discuss the patterns of the five identified trends in detail, putting Hungary in a comparative context with the general OECD trends. 


\section{Description of the overall trends}

As a result of changes in the shares of population sub-groups (Figure 1), households became smaller. The average household size declined by around 10\% in Hungary as well as across the OECD in general, from 2.6 and 2.8 respectively in the 1990s, to 2.3 and 2.5 today. This phenomenon is likely to increase overall inequalities ceteris paribus, as smaller households are less able to benefit from economies of scale resulting from pooling resources and sharing expenses.

Figure 1: Population shares of selected socio-demographic groups across OECD and in Hungary, mid-1990s and latest year in 2010s

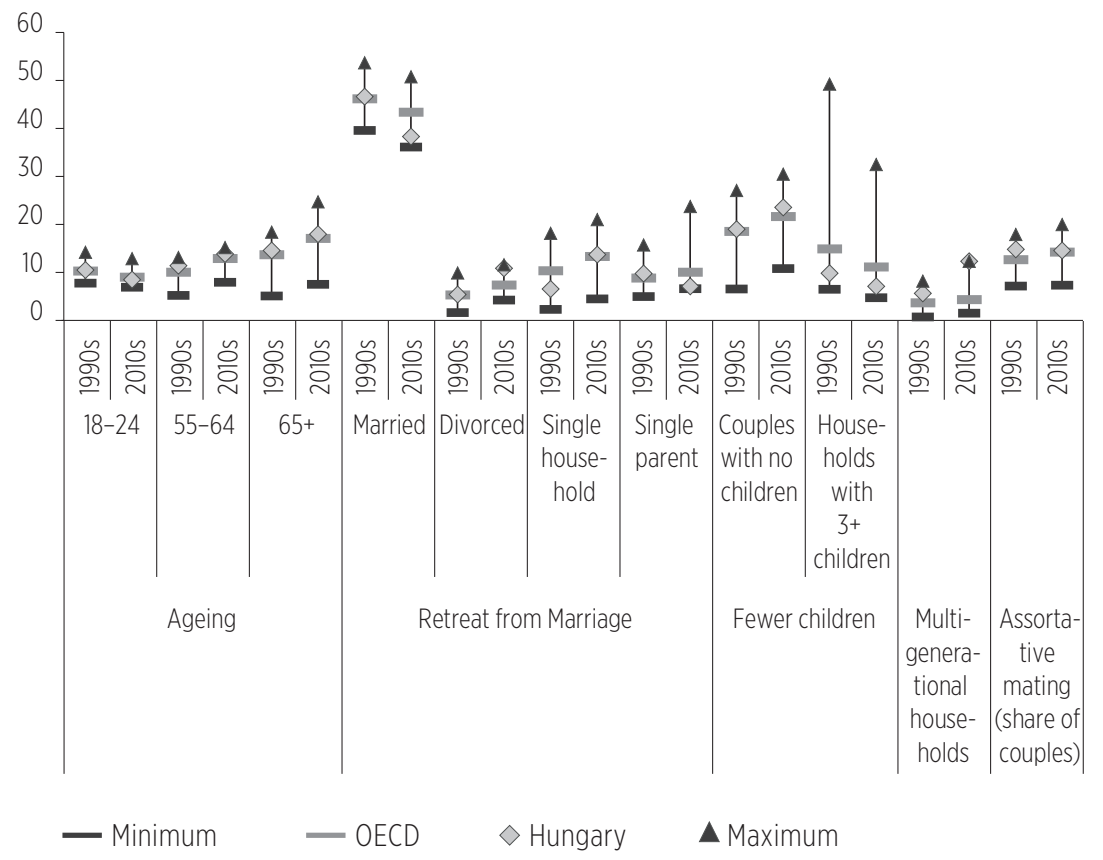

Note: All shares refer to shares of total population apart from assortative mating, which refers to share of couples. Multigenerational households refer to households where adults live with their parents and/or grandparents (this category also includes co-location of non-related adults). Assortative mating is defined as partners who belong to the same or adjacent income deciles. OECD refers to unweighted average of OECD countries for which data was available.

Source: OECD, in press; own calculations are based on the Luxembourg Income Study.

Relative incomes of some of the examined groups polarised further over the past two decades both in Hungary and across the OECD (Figure 2). Typically, the income positions of groups with lower relative incomes decreased or stagnated 
(e.g. single parents, or families with many children), while the position of those with higher relative income levels increased further (e.g. married couples). This again is likely to have contributed to an overall increase in inequalities. There are, however, some notable exceptions, as the relative position of some low-income groups increased, such as that of the elderly or single households, where the increase was particularly strong in Hungary.

Figure 2: Relative income levels of selected socio-demographic groups as a percentage of average income level of the total population across OECD and in Hungary, mid-1990s and latest year in 2010s

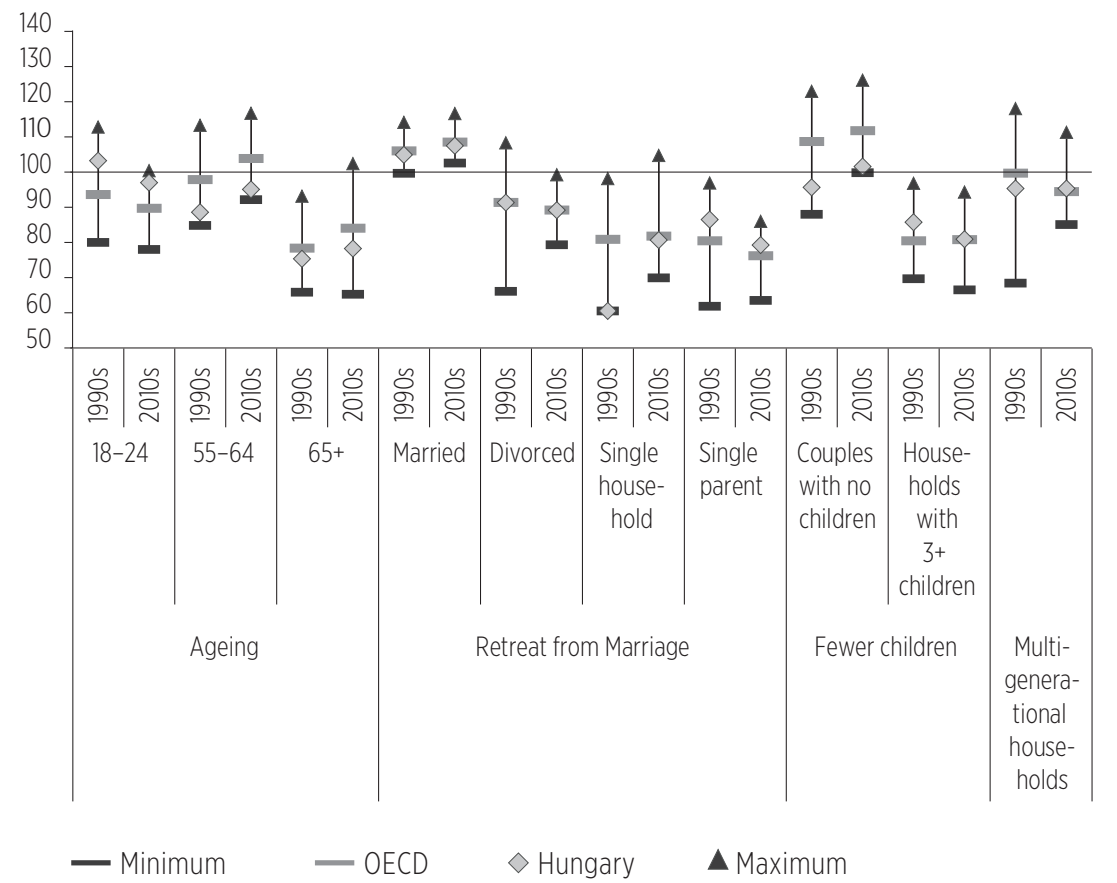

Note: Disposable income including tax benefits and other than market income. Compares the income of these socio-demographic groups to the average household income (black line). Average income levels refer to total population, except for age groups (working-age population). Multigenerational households include adults living with their parents and/or grandparents (category also includes co-location of non-related adults). OECD refers to unweighted average of OECD countries for which data was available.

Source: OECD, in press; own calculations are based on the Luxembourg Income Study. 
Income inequality within most population groups declined in Hungary, in line with the overall decline of the Gini coefficient over the period, and in some cases considerably (Figure 3). Across the OECD, income inequality within the examined groups did not change considerably and decreased slightly for some of the higher-inequality groups such as divorced, single parents or couples with no children. A push towards higher overall inequality levels hence seems rather due to increasing disparities between the examined socio-demographic groups rather than larger inequalities within them.

Figure 3: Income inequality within selected socio-demographic groups compared to the Hungarian mid-2010 average (horizontal line), mid-1990s and latest year in 2010s

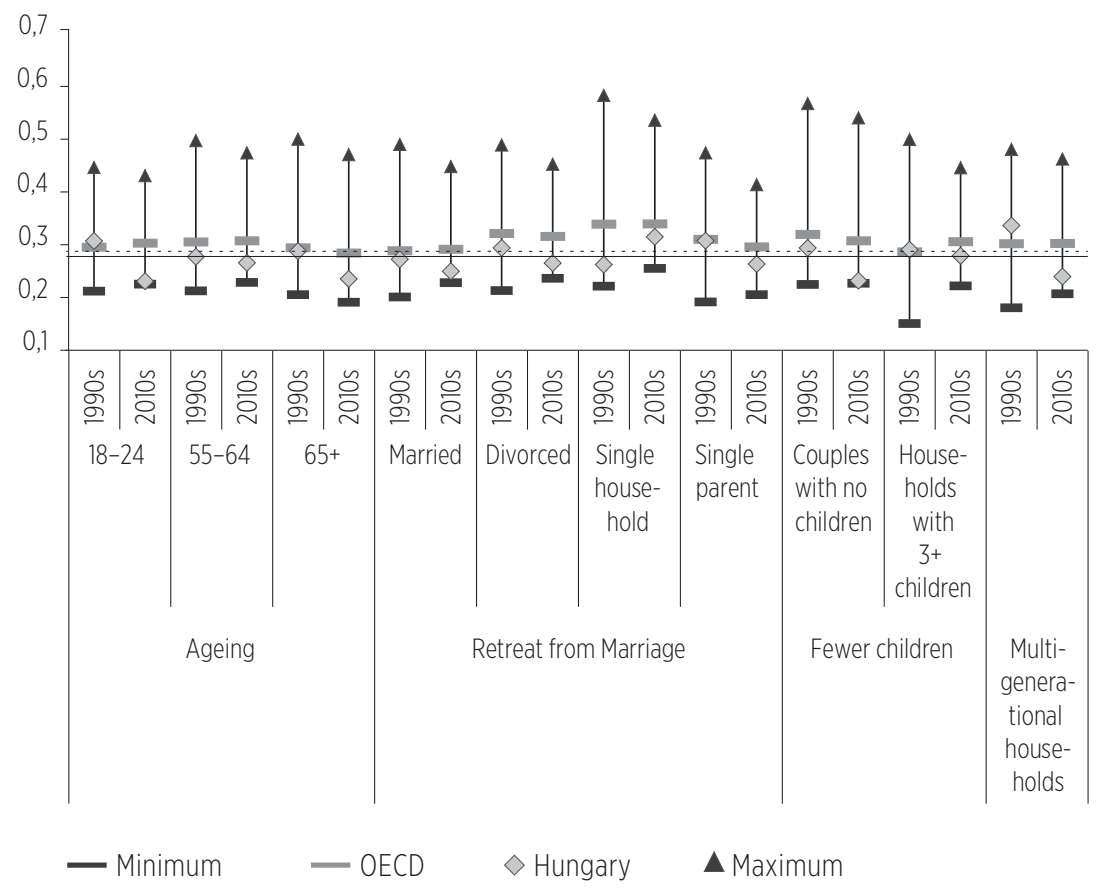

Note: Gini coefficients of disposable income. Compares the inequality within selected socio-demographic groups to the Hungarian average Gini in mid-2010s (black line) and in mid-1990s (dotted line). The category of multigenerational households includes adults living their parents and/or grandparents (category also includes colocation of non-related adults). OECD refers to unweighted average of OECD countries for which data was available. Source: OECD, in press; own calculations are based on the Luxembourg Income Study. 


\section{Young people's relative income has fallen but remained higher than those of older people}

The Hungarian population has been ageing rapidly over the past two decades due to an increase in life expectancy and a fall in fertility. Today, the median age of the population is 42 years, up from 36 in the mid-1990s (UN Population data). Over the past decades, the share of children (0-17) decreased, while the shares of those aged 51 and above increased in Hungary (Figure 1 above). The OECDwide trend is similar, although somewhat slower.

Over the past two decades, the relative incomes of youth (18-25) decreased in Hungary as well as across the OECD, while that of older age groups (55+) increased (Figure 2 above). The financial crisis resulted in worsening economic positions of youth (via higher risks of unemployment and precariousness, lower possibilities for wealth accumulation, in particular housing) relative to older ones (Arundel and Ronald, 2015). Under a generational perspective, those born in the 1960s and later on have enjoyed less favourable real income trends throughout their life than the generation of the "baby boomers", feeding into inter-generational inequality. This pattern prevails particularly in Hungary, while exceptions include most of the other Central European countries (OECD, 2017a). Later entry of youth and later exit of older adults to/from the labour market over the examined period could have contributed to this trend.

That said, in terms of levels, relative incomes of youth still fare better than those of older age groups in Hungary, while, across the OECD, both younger and older (65+) age groups tend to have lower relative incomes than adults at the end of their working careers (55-64).

Trends in within-group inequality by age were considerably different in Hungary from the OECD average (Figure 3). In Hungary, income inequality decreased for all age groups, but the most among young adults. While, on average across the OECD, inequality slightly increased or stagnated for all age groups (apart from those above 65) and by the most for the youngest groups. Falling inequality among young adults (18-24) can be observed in all four Visegrad countries (Czech Republic, Hungary, Poland and the Slovak Republic), but the largest fall happened in Hungary (by 8 percentage points). This specific feature may arise because, unlike in other OECD countries, the share of NEETs ${ }^{2}$ did not increase in these countries after the financial crisis and youth unemployment is lower than across the OECD (European Commission, 2016). Emigration of young and high-

${ }^{2}$ Not in employment, education or training 
skilled adults is likely an important reason as well that leads to labour shortages and increasing wages of those remaining (Hárs, 2018).

\section{Retreat from marriage and increase in single households was particularly rapid in Hungary}

The share of married people has declined sharply over the past decades in Hungary with a fall by one fifth to one of the lowest values across the OECD, 38\% (Figure 1). The OECD-wide trend was similar, although somewhat less strong. This phenomenon is linked to people getting married at an older age as both men and women aspire to establish themselves in the labour market and achieve economic security before founding a family (Smock and Schwarz, 2020). In line with this, the share of cohabiting couples increased in Hungary as well as on average across the OECD. Cohabitation provides an in-between step for young couples, and an increasing share of couples might choose not to marry due to changing culture and preferences (Spéder, 2019). Cohabitation also became more socially acceptable over the previous decades, which contributed to this steep increase (Thornton and Philipov, 2009).

The fall in married population is mirrored by an increase in the share of those who are divorced or separated. This trend was also particularly strong in Hungary as their share more than doubled since the mid-1990s, reaching $11 \%$ of the population (Figure 1). OECD-wide, divorce rates stabilised over the past decades, especially for highly educated individuals (OECD, 2019c). Some researchers have identified women's employment and a better economic position as an important contributor to rises in divorce, however evidence is inconclusive in this respect (Raley and Sweeney, 2020). Other reasons behind higher divorce rates are that people are living longer, second marriages are more likely to end in divorce and in some OECD countries, divorce became more socially acceptable.

There has been an increase in the share of single and single parent households. The share of single person households doubled to $13.5 \%$ in Hungary while it increased from 10\% to 13\% across the OECD (Figure 1). The increase might be due to later marriages, less stable relationships, or that elderly members of the family live in a good health longer and have more resources, which enables them to live independently (OECD, 2011a). In parallel, family structures became more heterogeneous, with an increasing variety of family types and arrangements (Cherlin, 2010). The share of births outside of marriage increased in all OECD countries over the past decades, while it more than doubled in Hungary to $47 \%$. 
On average across the OECD, there has also been an increase in the share of single parent families, from $8.5 \%$ to almost 10\%. In Hungary, however, the share of such families decreased from an average level to the minimum value in the OECD according to LIS data. ${ }^{3}$

Those who are married have a disposable household income which is almost $10 \%$ higher than the average and $20 \%$ higher than that of the divorced population (Figure 2). The income position of these two groups further polarised since the mid-1990s in Hungary as well as across the OECD: while the relative income of married people improved on average by 2.5 percentage points, the relative income of the divorced population further deteriorated by 2 percentage points. One underlying reason might be that married people are increasingly highly educated, which is associated with higher earnings (OECD, 2012). Marriage may have come to be seen as a luxury good, perhaps making it less available to those without higher education and certain economic security (Smock and Schwarz, 2020). Moreover, marriages today increasingly happen at older age, which is associated with higher married women's wages, further increasing the income position of this group (Martin, 2002). In many countries including Hungary, a number of tax exemptions or benefits are only available for married couples, contributing to higher relative income of this group.

The relative incomes of single and single parent households are considerably below the average of the total population, around 20\% lower (Figure 2 above). While the income position of single person households increased remarkably in Hungary from the lowest value across the OECD (61\%) catching up to the average (81\%), the OECD average remained unchanged over the past twenty years. It may be that in many countries it is increasingly higher income individuals who can afford living alone due to soaring housing prices. The relative incomes of single parent households deteriorated further, by $8 \%$ in Hungary (to $80 \%$ of the population average) and by $5 \%$ across the OECD (to $77 \%$ ). The high risk of poverty among these families has been widely documented (Thévenon et al., 2018). One contributing factor might be that the income-increasing effect of social transfers paid to single parent households declined across the OECD since the 1980s (OECD, 2011b). For example, in Hungary the level of the main benefits available for families on low income or precarious employment position (that typically characterises single parents) have not been adjusted, leading to benefit erosion (Makay, 2020).

${ }^{3}$ It should be noted that the Hungarian micro census shows an increasing trend in the share of single parent households, although for a somewhat different period; between 1990 and 2016 from $10.6 \%$ to $11.7 \%$. 
Among the examined groups, the level of income inequality is the lowest among married people and the highest among single households, both in Hungary and across the OECD (Figure 3). Single households are made up of a variety of groups, including youth who start their careers, parents after divorce or elderly members of the society, resulting in high heterogeneity. In Hungary inequality among married people decreased, while among single households it increased considerably, by around 5 Gini points. In contrast across the OECD, the level of inequality within these two groups did not change since the mid-1990s. In Hungary, a smaller share of single households belongs to the bottom two quintiles than previously. It has become more of a middle- than a lower-class phenomenon, perhaps because fewer individuals with low salaries can afford to pay rent alone.

\section{Stronger than average decline in the number of children in Hungary}

There are fewer children per households today, in all OECD countries, due to both increase in childlessness and decline in the size of families. Women are increasingly having their first child at a later age due to longer time spent in education and with starting their careers. There is also a growing emergence of couples without children, often with both partners working, the so-called "double-income no kids" (DINKS). The share of couples with no children increased since the mid-1990s from $18.3 \%$ to $23.4 \%$ in Hungary and to $21.5 \%$ in the OECD (Figure 1). Increase in childlessness can be explained by changes in cultural norms (more individualistic and less religious norms), increase in gender equality or rational economic calculations (i.e. result of increasing economic uncertainty and cost of quality education) (Tanturri, et al., 2015). In Hungary and in Central Eastern European countries more generally there is a particularly large gap between childbearing intentions and actual childbearing (Kapitány and Spéder, 2020).

At the same time, the share of households with three or more children decreased, from $11 \%$ to $6 \%$ in Hungary (Figure 1). This trend might be explained by changes in values and the economy, which resulted in a preference for more investment in fewer children (Kanazawa, 2014). Postponement of first childbirth can also lead to fewer children as it narrows the age-interval in which women have their children (OECD, 2011b). Research also demonstrated a trickle-down effect; the fewer children one has, the fewer children her children are predisposed to have (Rodgers, et al., 2001). 
The relative income of couples with no children increased since the mid-1990 from $96 \%$ of the average income to 102\% in Hungary and from 109\% to $112 \%$ across the OECD (Figure 2). One of its reason is that this group is increasingly highly educated. In Hungary, lower educated made up more than half of this group in the mid-1990s, but by the mid-2010s this fell to 22\%. During this period, the share of higher educated tripled from $5 \%$ to $15 \%$. Women with tertiary education are more likely to be in a childless household in most OECD countries (OECD, 2011b).

Relative incomes of people living in households with three or more children are one fifth below those in other households. Their relative income position declined by 6 percentage points in Hungary since the 1990s, while it did not change across the OECD (Figure 2). An underlying reason for this decline in Hungary can be that it is increasingly lower educated parents who have three or more children (Monostori and Murinkó, 2020). Another contributing factor might be that the level of the main universal family benefits (e.g. family allowance) did not keep pace with inflation (Makay, 2020).

In Hungary, within-group inequality of couples with no children fall considerably, by 6 Gini points. On average across OECD countries it decreased more moderately, with 1.2 Gini points since the mid-1990s (Figure 3). Those in the top income quintile are overrepresented among couples with no children as they make up $22 \%$ of the group in Hungary and 26\% across the OECD. Since the mid-1990s the share of those belonging to the bottom quintile decreased, while those in the middle and at the top increased, contributing to lower within-group inequality both in Hungary and across the OECD.

Inequality among households with three or more children decreased slightly in Hungary, while it increased by 2 Gini points across the OECD (Figure 3). Contrary to the OECD-wide trend, in Hungary the share of people with three or more children belonging to the top income quintile declined by 8 percentage points, while the share of those in the middle three quintiles increased. In Hungary having three or more children is increasingly frequent among lower and middle-income classes, while across the OECD it has become more of an upper-class phenomenon. This points to the possibility that while across the OECD this group is transforming, in Hungary it became more homogenous.

\section{Increase in multigenerational households was the largest in Hungary}

The share of multigenerational households (adults living with their parents and/ or grandparents) in Hungary increased from $5 \%$ to $12 \%$, which was the starkest 
increase among OECD countries (Figure 1). On average across the OECD the share of this group increased from 3\% to 4\%, mostly since the second half of the 2000s. This increase was driven by a larger share of young adults staying under the same roof with their parents rather than increased demand for eldercare (DeSilver, 2016; OECD, 2019c; Monostori and Murinkó, 2020). Young adults today spend more time in education and training, which causes a delay in the age when they become financially independent (OECD, 2011a). Soaring housing prices also play a role in later exit from parents' home. There has been an increase in the incidence of young adults who return to live at his or her family home ("boomerang children"), especially when facing economic hardship or after the end of a cohabiting relationship (Tosi and Grundy, 2018). This phenomenon was particularly strong in Hungary, especially among the 25-29 age group (14\%) (Aassve, et al., 2013; DeSilver, 2016; OECD, 2019c).

Incomes of multigenerational households are below average, but above those of single and single parent households. Such living arrangements smooth household income, as they provide a safety net for some household members, but typically decrease the per capita income of some others. Their relative income position stayed the same in Hungary, while it declined across the OECD by 5 percentage points (Figure 2 above). In most countries, the shares of multi-generational households fell among the top income groups over the past two decades. In Hungary, there has been an increase in multigenerational co-residence in the bottom two quintiles and a considerable decrease in the fourth quintile. One possible explanation is that as the low-income groups' earnings did not keep up with housing prices, they became more inclined to co-reside, while the higher earners could increasingly afford to have their own independent homes.

Income inequality among multigenerational households is comparable to the average and decreased considerably in Hungary, while it remained stable over the past two decades across the OECD (Figure 3). This was also the case in other Central Eastern European countries such as the Czech Republic and Poland, signalling increasing homogeneity among this group in the region.

\section{The share of couples in assortative relationships did not increase in Hungary}

Across the OECD, the share of couples belonging to the same earning segments increased inter alia due to the rise in female labour force participation. Scholars argue that the institution of marriage has shifted from one based on specialization 
(in which wives specialize in domestic, while husbands specialize in market work) to one based on collaboration, in which both partners make market economic contributions to the household (Sweeney, 2002). However, the overall share of couples in assortative relationships did not increase in post-socialist countries including Hungary. This might be as in these countries women already had a strong labour force participation during socialism (Harcsa and Monostori, 2018).

Mirroring an OECD-wide trend, there are signs that the relative incomes of couples who belong to similar earnings brackets increased in Hungary, with assortative mating becoming more frequent among those with higher incomes. Educational assortative mating at the top might have increased as men and women are sorting based on education as a proxy for similar "lifestyles" underpinned by shared values, beliefs or interests as opposed to merely earnings potential (Schwartz, 2010).

Across the OECD, income inequality likely has increased among couples with similar income levels. Assortative mating increased for men and women from the fifth earnings decile and was particularly strong among the top three deciles, leading to a wider income distribution and larger inequality. Meanwhile assortative mating decreased for households among the bottom deciles, leading to more diversified incomes and less vulnerability of low-income households (Greenwood, et al., 2014). At the same time, women from the bottom three and four deciles also became less likely to marry men from the top five earning deciles. Changes in the economic foundations of marriage may have led to more men looking for partners from higher income brackets. In addition, due to increasing inequalities and wage dispersion, the economic costs of "marrying down" may become increasingly severe, increasing the stake for economic considerations in choosing a partner (Schwartz, 2010).

\section{Summary of the main socio-demographic trends}

The main socio-demographic trends in Hungary were mostly in line with the OECD, although with a few notable exceptions (Table 1). Similarities include family structures becoming increasingly complex and a growing disconnect between nuclear families and households. There has been a general retreat from marriage and a growth in both cohabitation and the share of single person households. As a result, births outside of marriage increased as well as the share of children living in other than two-parent family structures. The number of children per household decreased due to both delayed childbearing and fewer large families with three or more children. The share of multigenerational households in- 
creased due to later exit of young adults as well as the emerging phenomenon of 'boomerang children' due to the recession and worsening housing affordability. These changes in family structures fed into the broader cross-sectional development of ageing populations.

Opposing the OECD-wide trend, the share of single parent families did not increase in Hungary, still their income position deteriorated considerably. The share of couples in assortative relationships (the degree to which individuals marry within their own income group) remained around the same in Hungary, while it increased in most other OECD countries. Some further differences include the decline in inequality levels among youth contrary to the OECD-wide increase. Although trends in relative incomes of different age groups were in line with the OECD, young adults still have a higher relative income level in Hungary than older age groups (both 55-65 and 65+). The relative income and inequality among households with three or more children decreased, while it increased across the OECD, signalling that while this group is transforming across the OECD, it is becoming more homogenously low-income in Hungary.

Table 1: Qualitative summary of selected socio-demographic trends in Hungary, mid-1990s-mid2010 s

\begin{tabular}{|c|c|c|c|c|}
\hline Trends & Groups & $\begin{array}{l}\text { Change in } \\
\text { population } \\
\text { share }\end{array}$ & $\begin{array}{l}\text { Change } \\
\text { in relative } \\
\text { income } \\
\text { level }\end{array}$ & $\begin{array}{l}\text { Change } \\
\text { in group } \\
\text { inequality }\end{array}$ \\
\hline \multirow{3}{*}{ Ageing } & Younger age groups (18-24) & $\downarrow$ & $\downarrow$ & $\downarrow$ \\
\hline & $\begin{array}{l}\text { Working age at the end of } \\
\text { career }(55-65)\end{array}$ & $\uparrow$ & $\uparrow$ & $\downarrow$ \\
\hline & Older age groups $\left(65^{+}\right)$ & $\uparrow$ & $\uparrow$ & $\downarrow$ \\
\hline \multirow{4}{*}{ Retreat from marriage } & Married & $\downarrow$ & $\uparrow$ & $\downarrow$ \\
\hline & Divorced & $\uparrow$ & $\downarrow$ & $\downarrow$ \\
\hline & Single & $\uparrow$ & $\uparrow$ & $\uparrow$ \\
\hline & Single parents & $\uparrow$ & $\downarrow$ & $\downarrow$ \\
\hline \multirow{2}{*}{$\begin{array}{l}\text { Decline in the number of } \\
\text { children }\end{array}$} & Couples with no children & $\uparrow$ & $\uparrow$ & $\downarrow$ \\
\hline & Households with $3+$ children & $\downarrow$ & $\downarrow$ & $\downarrow$ \\
\hline $\begin{array}{l}\text { Multigenerational } \\
\text { households }\end{array}$ & Multigenerational households & $\uparrow$ & - & $\downarrow$ \\
\hline Assortative mating & Share of assortative mating & - & $\uparrow$ & $\uparrow$ \\
\hline
\end{tabular}

Note: Table refers to changes in the population share, relative income level and within group inequality in Hungary. The grey shapes highlight trends that differ from the OECD average.

Source: OECD, in press; analysis based on the Luxembourg Income Study. 
At the same time, some trends were much more pronounced in Hungary than in other OECD countries. Retreat from marriage was particularly strong as well as the increase in the share of single households. Their relative income position and within-group inequality increased very strongly too, signalling fundamental and rapid transformation to a higher income group. The increase in multigenerational households and boomerang children was the strongest in Hungary. It is possible that single parents increasingly returned to their parents' households due to rising house prices and to share childcare responsibilities.

\section{THE OVERALL IMPACT OF IDENTIFIED TRENDS ON INCOME INEQUALITY}

The results from shift-share analysis suggest that most demographic changes over the past twenty years had only a very limited impact on income inequality on average across the OECD. None of these trends would have increased the Gini coefficient by more than 1 percentage point. In Hungary, some of the trends are estimated to have a somewhat more sizable though still modest impact (Figure 4). The impact was typically larger on market than on disposable income inequality, which is consistent with previous evidence, highlighting the strong inequality mitigating effect of the tax-benefit systems (Dolls, et al., 2019). Additional decomposition analysis confirms that the inequality-increasing impact of some socio-demographic changes was stronger in certain countries including Hungary, while limited on average across the OECD (OECD, in press).

\section{Inequality impact of socio-demographic trends is comparatively higher in Hungary}

The impact of ageing on income inequality in Hungary has been very modest, despite that this has been one of the strongest trends across the OECD. This is in line with trends discussed above such as convergence between the relative incomes of age groups and declining within-group inequality of youth. In theory, a larger share of retired people in the population can contribute to a wider between-group inequality as they tend to have lower incomes than the working age population (Dolls, et al., 2018). However, their relative incomes increased, mitigating this impact. 
The growing prevalence of divorce, cohabitation, and the decline in single parent households on their own had a negligible impact on inequality. Still, the inequality increasing impact of cohabitation on disposable income was the second largest in Hungary across all OECD countries. The impact of these trends was similar or even slightly smaller on market than on disposable income inequality, particularly for the cohabiting and divorced population. This signals that tax-benefit systems had no cushioning effect on these trends in disposable income inequality, even a slightly inverse effect in the case of cohabitation.

In Hungary, the decline in the number of children is estimated to have widened market income inequality by 1.5 Gini points, one of the largest values across the OECD. This trend increased inequality as it is higher earners who have no or fewer children, which can further contribute to higher intergenerational inequality on the long run. In Hungary, the decline in fertility may be linked to better labour market positions of women rather than an increase in their participation, which was already high (Harcsa and Monostori, 2018). An explanation is that higher earning women are the least eager to bring on their shoulders the triple burden of market work, childcare and domestic work and are able negotiate this more effectively with their partners (Tanturri, et al., 2015). Domestic work is still overwhelmingly done by women and this imbalance usually deteriorates further when couples have children (Miranda, 2011; Harcsa and Monostori, 2018). At the same time, the opportunity costs of career breaks are larger for higher earning women.

The impact of the increase in multigenerational households was estimated to be negligible on inequality on its own. The increasing shares of multigenerational households can boost household numbers and therefore the ability to pool resources. Some household members might escape economic hardship, however not everyone is better off in the new larger households. This might have additional implications on intergenerational inequality as parents with a higher socio-economic status will have a larger capacity to help their children for an extended period.

The overall inequality impact of changing household types taken together (singles, single parents, couples with and without children, multigenerational households) is estimated to be higher. It had the second biggest impact in Hungary, increasing market income inequality by almost 2 Gini points and the disposable income inequality by 0.8 points (Figure 4). 
Figure 4: Estimated inequality impact of examined socio-demographic trends, mid-1990s and mid2010s, in Gini points

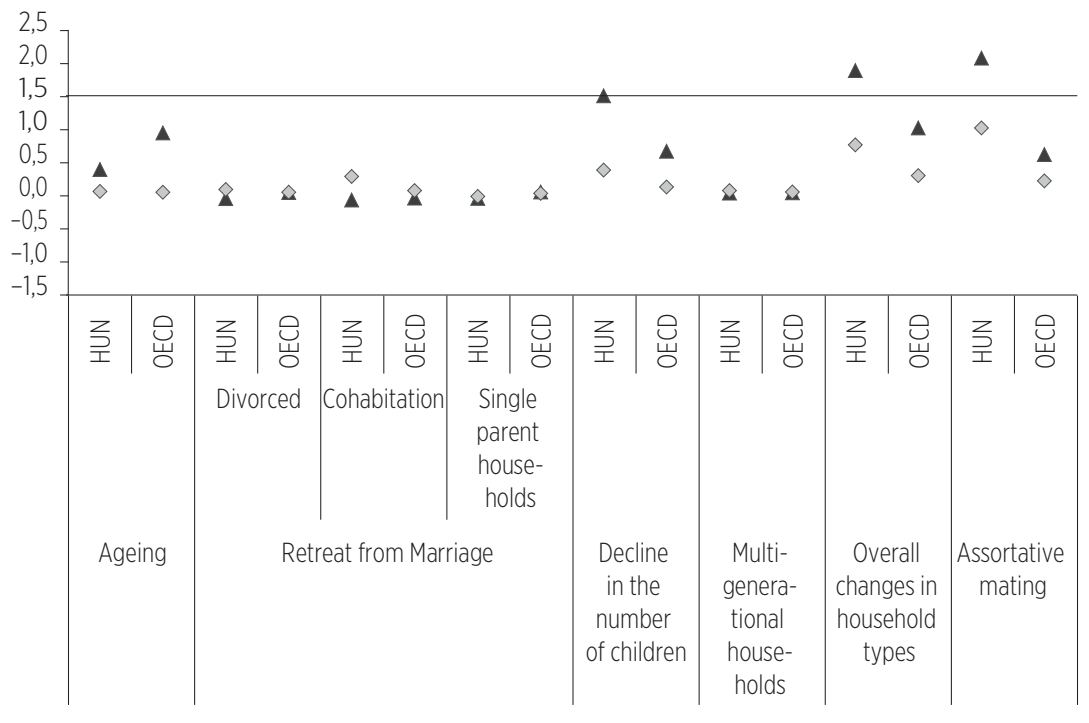

$\diamond$ Market income $\quad \Delta$ Disposable income

Note: The data points show the difference between actual and counterfactual changes of the Gini coefficient, for market income (triangle) and disposable income (diamond), respectively. Across the OECD, for instance, the Gini coefficient for market income was by 1 point higher than it would have been in the absence of ageing (it increased from 42.0 to 45.1, rather than 44.1). In Hungary, for instance, the Gini coefficient for disposable income was by 0.4 points higher than it would have been in the absence of the decline of the number of children (it decreased from 28.8 to 26.8 rather than 26.4). Household types refers to single persons, single parents, couples with children, couples without children and other, including multigenerational households. Data refer to the total population. The line signals 1.5 Gini points, considered to be the threshold indicating a significant impact. OECD refers to unweighted average of OECD countries for which data was available.

Source: OECD, in press; own calculations are based on the Luxembourg Income Study.

Changing assortative mating patterns had a larger impact too, and it was largest in Hungary: in their absence, market income inequality would be by 2 Gini points lower and disposable income inequality by 1 Gini point. As the share of assorted couples did not change in Hungary, this significant impact stems from changes of income patterns within this group and/or between assorted and non-assorted couples. Increasing correlation between spouses' income can amplify existing inequalities and the gap between households (OECD, 2011c; 2015). An important force behind increasing inequalities resulting from assortative mating is the rising gap between households with two high wage earners and those with only one middle or low wage earner. Couples relying on a single earner increasingly fall short of the middle of the income distribution, by con- 
trast couples with two full earners account disproportionately for upper income households (OECD, 2019s). Trends in assortative mating (in earnings and/or education) also contribute to the intergenerational transmission of inequalities through increasing disparity in human capital investment in children between families (Adema, et al., 2020; Becker, 1986; Black, 2011; Tuncay, 2019).

\section{Inequality impact of socio-demographic trends diverge across OECD countries}

The impact of most socio-demographic trends on disposable income inequality has been modest if not negligible on average across the OECD over the past two decades (Table 1 above, Table 2 below). Where they did have an effect, it was mostly - but not exclusively - upwards. One underlying reason behind this moderate effect might be that the impact of socio-demographic trends on inequality is not as straightforward as some studies suggest. The analysis above uncovered that trends lead to sometimes opposing effects due to interactions between changes in population shares, in relative income positions and in within-group inequality. For example, the share of elderly grew, but so did their income levels, mitigating the inequality increasing impact. Moreover, all of the trends had different impacts in at least some of the OECD countries, dragging down the OECD average (Table 2 below).

Table 2 shows that Central-Eastern European and Latin American OECD member countries, which joined the OECD more recently, were more frequentIy among the exceptions from the OECD-wide trend than older member countries. Poland and Mexico for example experienced an equalising impact of at least half of the examined demographic trends. On the other hand, this group of mostly emerging countries also more frequently recorded stronger inequality increasing impacts of some of the demographic trends. The largest increases occurred again in Mexico and some of the Central-Eastern European countries. These countries underwent a more considerable demographic transformation during the examined period. Germany and Austria were, however, also frequently among countries with considerable increases.

For most socio-demographic trends, the impact on disposable income inequality was more limited than on market income inequality (last column in Table 2), highlighting the cushioning effect of the tax-benefit systems. However, there were notable exceptions: changes in the share of divorced people, the share of cohabitation and the share of multi-generational households did not have a larger effect on market than on disposable income inequality. 
Table 2: Qualitative summary of estimated effects of socio-demographic trends on income inequality, mid-1990s-mid-2010s

\begin{tabular}{|c|c|c|c|c|c|}
\hline Trends & Indicator & $\begin{array}{l}\text { Impact on } \\
\text { disposable } \\
\text { income } \\
\text { inequality } \\
\text { in OECD }\end{array}$ & $\begin{array}{l}\text { Top } 5 \\
\text { countries } \\
\text { (largest } \\
\text { inequality } \\
\text { increasing } \\
\text { impact) }\end{array}$ & $\begin{array}{l}\text { Exceptions } \\
\text { form OECD- } \\
\text { wide trend } \\
\text { (inequality } \\
\text { decreasing } \\
\text { impact) }\end{array}$ & $\begin{array}{l}\text { Impact on } \\
\text { market } \\
\text { income } \\
\text { inequality } \\
\text { in OECD }\end{array}$ \\
\hline \multirow{5}{*}{ Retreat from marriage } & $\begin{array}{l}\text { Change in age structure } \\
\text { (all age groups) }\end{array}$ & 0.0 & $\begin{array}{l}\text { MEX, FIN, } \\
\text { CHE, AUT, } \\
\text { USA }\end{array}$ & $\begin{array}{l}\text { POL, ESP, } \\
\text { ITA, CZE }\end{array}$ & +0.8 \\
\hline & $\begin{array}{l}\text { Increase in divorced } \\
\text { population }\end{array}$ & 0.0 & $\begin{array}{l}\text { GRC, AUT, } \\
\text { DEU, CZE, } \\
\text { ESP }\end{array}$ & $\begin{array}{l}\text { AUS, CAN, } \\
\text { SVN, MEX }\end{array}$ & 0.0 \\
\hline & Increase in cohabitation & +0.1 & $\begin{array}{l}\text { MEX, HUN, } \\
\text { CZE, SVN, } \\
\text { DEU }\end{array}$ & $\begin{array}{l}\text { GBR, LUX, } \\
\text { CHL, AUS, } \\
\text { DNK }\end{array}$ & 0.0 \\
\hline & $\begin{array}{l}\text { Increase in single } \\
\text { parents }\end{array}$ & 0.0 & $\begin{array}{l}\text { IRL, ITA, } \\
\text { DEU, NLD, } \\
\text { LUX }\end{array}$ & $\begin{array}{c}\text { MEX, USA, } \\
\text { CAN, SVK, } \\
\text { CHL, HUN, } \\
\text { CHE, FIN, } \\
\text { SVN, CZE, } \\
\text { GRC, DNK, } \\
\text { POL }\end{array}$ & +0.1 \\
\hline & $\begin{array}{l}\text { Changing household } \\
\text { types }\end{array}$ & +0.3 & $\begin{array}{l}\text { SVN, MEX, } \\
\text { HUN, DEU, } \\
\text { AUT }\end{array}$ & $\begin{array}{l}\text { POL, ESP, } \\
\text { GRC }\end{array}$ & +1 \\
\hline Number of children & $\begin{array}{l}\text { Decline in the share of } \\
\text { children }\end{array}$ & +0.1 & $\begin{array}{l}\text { MEX, SVN, } \\
\text { FIN, AUT, } \\
\text { HUN }\end{array}$ & $\begin{array}{l}\text { ESP, POL, } \\
\text { ITA, LUX, } \\
\text { GRC, GBR, } \\
\text { CHE, CZE }\end{array}$ & +0.6 \\
\hline $\begin{array}{l}\text { Multigenerational } \\
\text { households }\end{array}$ & $\begin{array}{l}\text { Increase in } \\
\text { multigenerational } \\
\text { households }\end{array}$ & +0.3 & $\begin{array}{l}\text { CHL, GRC, } \\
\text { SVN, ESP, } \\
\text { FRA }\end{array}$ & $\begin{array}{l}\text { MEX, SVK, } \\
\text { GBR, USA, } \\
\text { FIN, POL }\end{array}$ & +0.2 \\
\hline Assortative mating & $\begin{array}{l}\text { Increase in assortative } \\
\text { mating }\end{array}$ & +0.2 & $\begin{array}{l}\text { HUN, CZE, } \\
\text { LUX, DEU, } \\
\text { NLD }\end{array}$ & $\begin{array}{l}\text { MEX, ISR, } \\
\text { POL, CHL, } \\
\text { ITA, IRL, } \\
\text { CHE }\end{array}$ & +0.6 \\
\hline
\end{tabular}

Note: Table refers to changes in the Gini index in points for working age population resulting from the shift-share analysis. 'Top 5 countries' refer to the largest estimated disposable income inequality increases due to the respective trends. Exceptions refer to all countries, where disposable income inequality is estimated to decrease due to the respective trends. Changing household types refer to overall impact of change in multiple household types (single person, single parent, couples with children and couples without children). OECD refers to unweighted average of OECD countries or for which data was available. Country abbreviations refer to the following countries: AUS (Australia), AUT (Austria), CAN (Canada), CHE (Switzerland), CHL (Chile), CZE (Czech Republic), DEU (Germany), DNK (Denmark), ESP (Spain), FIN (Finland), FRA (France), GBR (United Kingdom), GRC (Greece), HUN (Hungary), ITA (Italy), IRL (Ireland), ISR (Israel), LUX (Luxembourg), MEX (Mexico), NLD (The Netherlands), POL (Poland), SVN (Slovenia), SVK (Slovak Republic), USA (United States of America).

Source: OECD, in press; analysis is based on the Luxembourg Income Study. 


\section{POLICY IMPLICATIONS AND VARIOUS POLICIES TO MITIGATE THE INEQUALITY INCREASING IMPACT OF SOCIO-DEMOGRAPHIC TRENDS IN HUNGARY}

The welfare state plays an important role in cushioning the overall inequality increasing impact of socio-demographic changes on disposable income, through its tax and benefit system. Still, there exist a number of additional policy streams and options that could further mitigate trends to increasing income inequality triggered by demographic trends. This could entail additional benefits such as lower poverty, higher fertility and improved female labour market position. Based on the findings of the analysis above, promising policies in the Hungarian context would focus particularly on mitigating the inequality increasing impact of assortative mating, changing household types, childlessness and ageing.

Improving the labour market position and earning potential of women

An important force behind increasing inequalities resulting from assortative mating is the rising gap between households with two high wage earners and those with only one middle or low wage earner (OECD, 2019a). Having more women in full-time work lowers household income inequality, despite the inequality increasing impact of assortative mating (OECD, 2011c; 2015). Policies that increase the labour market participation and the earnings potential of lower-paid women (who typically have lower skills and educational attainment) have the largest potential benefits (OECD, 2017b). Accessible, affordable and flexible early childhood education is key. Countries with a combination of heavily-subsidised, income-tested fees and sufficient supply, such as Denmark, Iceland and Sweden, have more equal child outcomes and higher shares of employed mothers (OECD, 2017b). Second chance programmes can increase the earning and employment potential of women in a polarising labour market. Designing training programmes in modular format, providing advice and guidance and active outreach are essential especially to the most disadvantaged groups (OECD, 2019f).

\section{Adapting the legal framework and tax-benefit rules to changing family structures}

Family living arrangements have become increasingly fluid over recent decades, but legal frameworks and tax-benefit rules still do not regard all fami- 
Iy living arrangements the same way and often treat married and unmarried families differently. Social protection systems are not always prepared for the new socio-economic risks generated by cohabiting or reconstituted families. For example, parental obligations can differ in case of divorce or separation (Miho and Thévenon, 2020). This is particularly true for Hungary, where multiple family benefits are only available for married couples. Family policies were implemented in a context where having children was associated with marriage. However, targeting policies at married people nowadays does not equal targeting families with children. Legal frameworks and tax-benefit rules need to be adapted to fluid family arrangements to avoid some population groups falling through social protection. For example, the neutrality of tax-benefit rules regarding marital status can be largely enhanced.

\section{Removing barriers to family formation}

The decline in the number of children in Hungary tended to increase inequality (see Figure 4) inter alia as childlessness is higher among those with high educational attainment and commitment towards their careers (Harcsa and Monostori, 2018). However, this might not be a preferred choice. In all OECD countries the number of children women intend to have is higher than the actual number they end up having (OECD, 2019d). This gap is particularly large in Hungary and other Central-Eastern European countries, given that gender roles are more traditional than in many OECD countries, hence domestic and care responsibilities still fall overwhelmingly on the shoulders of women even if they are working (Kapitány and Spéder, 2020). Conversely, in countries where working women are not overloaded by domestic duties and where men are more collaborative (i.e. in Nordic countries), couples are more likely to have (or to wish to have) a further child (Tanturri, et al., 2015). Policies that help to reconcile work and care obligations of women could hence lead to higher fertility. Parental leave quotas exclusively available for fathers ('take it or lose it') and bonuses in case of take-up (in the form of additional leave for the couple) result in more equal distribution of care responsibilities on the long run. Evidence suggests that flexible work, cash benefits covering childhood years and provision of childcare services for children under age three seem to have a larger potential influence on fertility than leave entitlements and benefits granted around childbirth. Meanwhile pro-natal policies that do not protect women's positions in the labour market may fail to raise fertility levels significantly (Thévenon, 2015). 


\section{Improving relative incomes of pensioners and preventing ageing unequally}

In Hungary, the relative income of the elderly is well below that of working-age adults and young adults. The minimum pension is comparatively low and has not been adjusted since 2008; as a result, some $20 \%$ of pensioners receive pensions below the relative income poverty line (defined as half the median income). The impact of career breaks on pension entitlements is larger than elsewhere in the OECD. At the same time the earnings-related pension system secures good pensions for individuals with high incomes and full careers, fuelling inequality among pensioners (OECD, 2019e). With the current rules unchanged, the Hungarian pension system could become one of the most unequal within the OECD. In parallel an increasing share of the population will be made up of pensioners due to ageing. As a result, policies that prevent increasing inequality among this group are of high importance. First-tier pensions with embedded redistributive components in benefit and/or contribution rules mitigate inequalities effectively. As in Hungary coverage is high, but the replacement rate is comparatively low, possible policy options could include increasing the minimum pension and strengthening progressivity of the pension system (OECD, 2017a)

\section{SUMMARY AND CONCLUSION}

Socio-demographic trends over the past twenty years in Hungary were largely in line with OECD-wide trends. There has been a general retreat from marriage and a growth in both cohabitation and multigenerational households as well as in the share of single person households. Births outside of marriage increased as well as the share of children living in other than two-parent family structures and the number of children per household decreased. These changes in family structure fed into the broader cross-sectional development of ageing populations.

However, most of these demographic changes had only a modest (upward) impact on trends in income inequality. In Hungary, three of the examined trends had a more significant impact than in other OECD countries: assortative mating, decline in the number of children and changes in household types taken together. Meanwhile, ageing had a smaller impact than elsewhere, in line with the observation that the incomes of younger and older adults converged instead of growing more unequal. The inequality impact was typically larger on market 
than on disposable incomes, highlighting the strong inequality mitigating effect of the tax-benefit systems.

Based on these findings, promising policies in the Hungarian context that would curb trends to increasing inequalities would focus on removing barriers to family formation; improving the labour market position and earning potential of women; adapting legal framework and tax-benefit rules to changing family structures; and improving relative incomes of pensioners and preventing ageing unequally. 


\section{REFERENCES}

Aassve, A., Cottini, E. and Vitali, A., 2013. Youth prospects in a time of economic recession. Demographic Research, 29, pp. 949-962.

Adema, W., Clarke C. and Thévenon, O., 2020. Family policies and family outcomes in OECD countries. In: R. Nieuwenhuis and W. V. Lancker, eds. The Palgrave Handbook of Family Policy. Cham: Palgrave Macmillan. pp. 193-217.

Arundel, R. and Ronald, R., 2015. Parental co-residence, shared living and emerging adulthood in Europe: semi-dependent housing across welfare regime and housing system contexts. Journal of Youth Studies, 19(7), pp. 885-905.

Becker, G. and Tomes, N., 1986. Human capital and the rise and fall of families. Journal of Labor Economics, 4(3), pp. S1-S39.

Black, S. E. and Devereux, P. J., 2011. Recent developments in intergenerational mobility. In: D. Card and O. Ashenfelter, eds. Handbook of Labor Economics. Vol. 4B. Elsevier. pp. 1487-1541.

Cherlin, A. J., 2010. Demographic trends in the Unites States: A Review of Research in the 2000s. Journal of Marriage and Family, 72(3), pp. 403-410.

DeSilver, D., 2016. In the U.S. and abroad, more young adults are living with their parents. [online] Pew Reasearch Center. Available at: https://www. pewresearch.org/fact-tank/2016/05/24/in-the-u-s-and-abroad-moreyoung-adults-are-living-with-their-parents/.

Dolls, M., Doorley, K., Paulus, A., Schneider, H. and Sommer, E., 2018. Demographic Change and the European Income Distribution. IZA Institute of Labor Economics Discussion Paper Series, Vol. 11440.

Dolls, M., Doorley, K., Paulus, A., Schneider, H. and Sommer, E., 2019. Demographic change and the European income distribution. The Journal of Economic Inequality, 17(3), pp. 337-357.

European Commission, 2016. Employment and Social Development in Europe 2016. Publication Office of the EU. Available at: https://op.europa.eu/en/publication-detail/-/publication/8d0b1be0-d95d-11e6-ad7c-01aa75ed71a1/language-en.

Förster, M. F. and Tóth, I. Gy., 2015. Cross-Country Evidence of the Multiple Causes of Inequality Changes in the OECD Area. In: A. B. Atkinson and F. Bourguignon, eds. Handbook of Income Distribution. Vol. 2B. Elsevier, pp. 1729-1843.

Förster, M. and Vindics, A., 2020. Demográfiai és családszerkezeti változások hatása a jövedelemeloszlásra Magyarországon és az OECD-országokban. In: T. Kolosi, I. Szelényi and I. Gy. Tóth eds. Társadalmi riport 2020. Budapest: TÁRKI, pp. 171-196.

Greenwood, J., Guner, N., Kocharkov, G. and Santos, C., 2014. Marry Your Like: Assortative Mating and Income Inequality. American Economic Review, 104(5), pp. 348-353. 
Grégoire-Marchand, P. and Frémeaux, N., 2018. Le couple contribue-t-il encore à réduire les inégalités. La Note D’Analyse, 71. Paris: France Stratégie.

Harcsa, I. and Monostori, J., 2018. A háztartás és családszerkezeti változások hosszútávú trendjei Magyarországon európai kontextusban: Teóriák, tévképzetek, tények. Demográfia, 60(4), pp. 299-332.

Hárs, Á., 2018. Növekvő elvándorlás - lehetőségek, remények, munkaerőpiaci hatások. In: T. Kolosi and I. Gy. Tóth, eds. Társadalmi Riport 2018. Budapest: TÁRKI, pp. 81-105

Kanazawa, S., 2014. Intelligence and childlessness. Social Science Research, 48(3), pp. 157-170.

Kapitány, B. and Spéder, Zs., 2020. Fertility. In: J. Monostori, P. Öri and Zs. Spéder, eds. Demographic Portrait of Hungary 2018. Budapest: Hungarian Demographic Research Institute, pp. 49-66.

Keeley, B., 2015. Income Inequality: The Gap between Rich and Poor. Paris: OECD Publishing.

Makay, Zs., 2020. The Family Support System and Female Employment. In: J. Monostori, P. Őri and Zs. Spéder, eds. Demographic Portrait of Hungary 2018. Budapest: Hungarian Demographic Research Institute, pp. 85-105.

Martin, S. P., 2002. Delayed Marriage and Childbearing: Implications and Measurement of Diverging Trends in Family Timing. College Park: University of Maryland.

Miho, A. and Thévenon, O., 2020. Treating all children equally? Why policies should adapt to evolving family living arrangements. OECD Social, Employment and Migration Working Papers, No. 240. Paris: OECD Publishing.

Miranda, V., 2011. Cooking, Caring and Volunteering: Unpaid Work Around the World. OECD Social, Employment and Migration Working Papers, 116. Paris: OECD Publishing.

Monostori, J. and Murinkó, L., 2020. Household and Family Structure. In: J. Monostori, P. Öri and Z. Spéder, eds. Demographic Portrait of Hungary 2018. Budapest: Hungarian Demographic Research Institute, pp. 179-199.

OECD, 2011a. The Future of Families - Synthesis report. Paris: OECD Publishing.

OECD, 2011b. Doing Better for Families. Paris: OECD Publishing.

OECD, 2011c. Divided We Stand: Why Inequality Keeps Rising. Paris: OECD Publishing.

OECD, 2012. Education at a Glance 2012: Highlights. Paris: OECD Publishing.

OECD, 2015. In It Together: Why Less Inequality Benefits All. Paris: OECD Publishing.

OECD, 2017a. Preventing Ageing Unequally. Paris: OECD Publishing.

OECD, 2017b. The Pursuit of Gender Equality: An Uphill Battle. Paris: OECD Publishing.

OECD, 2018. A Broken Social Elevator? How to Promote Social Mobility. Paris: OECD Publishing.

OECD, 2019a. Under Pressure: The Squeezed Middle Class. Paris: OECD Publishing. 
OECD, 2019b. Income Distribution Database (IDD): Gini, poverty, income, Methods and Concepts. [online] Available through: OECD, http://www.oecd.org/ social/income-distribution-database.htm.

OECD, 2019c. Society at a Glance 2019: OECD Social Indicators. Paris: OECD Publishing.

OECD, 2019d. OECD Family Database. [online] Available through: OECD, http://www.oecd.org/els/family/database.htm.

OECD, 2019e. OECD Economic Surveys: Hungary 2019. Paris: OECD Publishing.

OECD, 2019f. Getting Skills Right: Engaging low-skilled adults in learning. Paris: OECD Publishing.

OECD, (in press). OECD-EC report on the impact of shifting demographic and family structures on income inequality and its policy implications. Paris: OECD Publishing.

Raley, R. K. and Sweeney, M. M., 2020. Divorce, Repartnering, and Stepfamilies: A Decade in Review. Journal of Marriage and Family, 82(1), pp. 81-99.

Rodgers, J. L., Hughes, K., Kohler, H. P., Christensen, K., Doughty, D., Rowe, D. C. and Miller, W. B., 2001. Genetic Influence Helps Explain Variation in Human Fertility: Evidence From Recent Behavioral and Molecular Genetic Studies. Current Directions in Psychological Science, 10(5), pp. 184-188.

Schwartz, C., 2010. Earnings Inequality and the Changing Association between Spouses' Earnings. American Journal of Sociology, 115(5), pp. 1524-1557.

Smock, P. J. and Schwarz, C. R., 2020. The Demography of Families: A Review of Patterns and Change. Journal of Marriage and Family, 82(1), pp. 9-34.

Spéder, Zs., 2019. Demographic Trends: Fertility, Mortality, Ageing. In: I. Gy. Tóth, ed. Hungarian Social Report 2019. Budapest: TÁRKI, pp. 13-31.

Sweeney, M. M., 2002. Two Decades of Family Change: The Shifting Economic Foundations of Marriage. American Sociological Review, 67(1), pp. 132-147.

Tanturri, M. L., Mills, M., Rotkirch, A., Sobotka, T., Takács, J., Miettinen, A., Faludi, C., Kantsa, V. and Nasiri, D., 2015. State-of-the-art report: Childlessness in Europe. Families and Societies Working Paper Series, 32, pp. 1-53.

Thévenon, O., 2015. Decreasing Fertility in Europe: Is it a Policy Issue? In: K. Matthijs, K. Neels, C. Timmerman, J. Haers and S. Mels, eds. Population Change in Europe, the Middle-East and North Africa: Beyond the Demographic Divide. Burlington: Ashgate. pp. 81-118.

Thévenon, O., Manfredi, T., Govind, Y. and Klauzner, I., 2018. Child poverty in the OECD: Trends, determinants and policies to tackle it. OECD Social, Employment and Migration Working Papers, 218. Paris: OECD Publishing.

Thornton, A. and Philipov, D., 2009. Sweeping Changes in Marriage, Cohabitation and Childbearing in Central and Eastern Europe: New Insights from the Developmental Idealism Framework. European Journal of Population / Revue européenne de Démographie, 25(2), pp. 123-156.

Tosi, M. and Grundy, E., 2018. Returns home by children and changes in parents' well-being in Europe. Social Science and Medicine, 200, pp. 99-106.

Tuncay, M. A., 2019. Assortative Mating and Inequality. PhD. The University of Chicago. Available at: https://knowledge.uchicago.edu/record/1881. 